\section{Effect ofNon-Thermal Argon Plasma on Bond Strength of a Self-Etch Adhesive System to NaOCl-Treated Dentin}

\author{
João Luiz Bittencourt de Abreu1, Maíra Prado ${ }^{1,2}$, Renata Antoun Simão², \\ Eduardo Moreira da Silva ${ }^{3}$, Katia Regina Hostilio Cervantes Dias ${ }^{1}$
}

\author{
'Department of Dental Clinic, \\ Dental School, UFRJ - Universidade \\ Federal do Rio de Janeiro, \\ Rio de Janeiro, RJ, Brazil \\ ${ }^{2}$ Laboratory of Polymer and Asphalt \\ Surfaces, School of Metallurgical \\ and Materials Engineering, UFRJ \\ - Universidade Federal do Rio de \\ Janeiro, Rio de Janeiro, RJ, Brazil \\ ${ }^{3}$ Analytical Laboratory of \\ Restorative Biomaterials, Dental \\ School, UFF - Universidade Federal \\ Fluminense, Niterói, RJ, Brazil
}

Correspondence: Dra. Maíra do Prado, Cidade Universitária, Centro de Tecnologia, Bloco F, sala F-201, llha do Fundão, 21941-972 Rio de Janeiro, RJ, Brasil. Tel: +55-21-39388526. e-mail: mairapr@hotmail.com

Key Words: sodium hypochlorite, dentin, dentin bonding agents, plasma gases, dental restoration

\section{Introduction}

The main goal of endodontic treatment is the complete apical and coronal seal of root canal system to prevent percolation and bacterial leakage (1). The infiltration of oral microorganisms through the filling of the root canals is favored by the absence of a correct coronal sealing, harming the prognosis of these treatments $(2,3)$.

The mechanic preparation is able to remove a great number of bacteria in the main canal, but there are areas that are not removed by the instruments, due to the complex anatomy of the root canal systems $(4,5)$. Many irrigating solutions have been used to reach those areas, and remove debris and necrotic tissue. Nowadays, the sodium hypochlorite $(\mathrm{NaOCl})$ is the most used auxiliary chemical substance among endodontists worldwide (6). This fact is due to this solution being the only with the capacity to tissue dissolution and broad-spectrum antimicrobial activity (7). However, during its action in the root canal, there is formation of free oxygen. This nascent oxygen causes a strong inhibition in the polymerization next to the interface of the adhesive materials (8). Because of this inhibition in polymerization, studies have been showing an increase of coronal micro-infiltration and a decrease in the levels of bond resistance in endodontically treated teeth (9-11). Solutions like ascorbic acid have been proposed to reduce this effect, but the required contact time for inhibition is too long and clinically unpractical (12).

The use of plasma technology has expanded its actuation area to obtain increase of surface wettability and, consequently, the bond resistance between interfaces of different compositions. This technology consists in chemical modification of a surface by a gas or a combination of gases. In dentistry, it was proposed aiming the increase in coronal adhesion levels (13), adhesion between fiber posts and resin cements (14) and in the disinfection of root canals (15). Different gases were used, including argon, EDA, helium and oxygen (13-16).

The objective of the present study was to evaluate the effect of non-thermal argon plasma on bond strength of a self-etch adhesive system to $\mathrm{NaOCl}$-exposed coronal dentin.

\section{Material and Methods}

\section{Specimen Preparation}

The crowns of 32 bovine incisors were separated from the roots and sectioned parallel to their long axis and through the pulp chamber using a diamond disc (KG Sorensen, Cotia, SP, Brazil). The dentin from the buccal halves of the crows were wet ground with silicon carbide paper 200, 500 and \#600 to produce flat dentin surfaces 
and standardize the thickness of the smear layer (17).

\section{Surface Treatments}

The dentin surfaces were immersed in $2.5 \% \mathrm{NaOCl}$ (Formulativa, Rio de Janeiro, RJ, Brazil) for $30 \mathrm{~min}$, in order to simulate the irrigation step during endodontic treatment, ultrasonically cleaned for $5 \mathrm{~min}$ and divided into four groups $(n=8)$ according to the surface treatments (Table 1$)$.

\section{Plasma Treatment}

A glass reactor was used for non-thermal plasma treatment. This reactor consists of a $5 \mathrm{~cm}$ diameter and $30 \mathrm{~cm}$ long tube, evacuated by a mechanical pump, down to pressures lower than $2 \mathrm{~Pa}$. Gas was allowed to fill the reactor up to a pressure of $10 \mathrm{~Pa}$. Non-thermal plasma was generated within the glass cylinder under vacuum by the action of an induced magnetic field from the current passing through an electrical coil surrounding the cylinder. Surfaces were treated using argon gas (White Martins, Rio de Janeiro, RJ, Brazil) at $60 \mathrm{~W}$ for 15,30 or $45 \mathrm{~s}$. At the end of the process, radio frequency was turned off before the samples were exposed to air.

\section{Microtensile Test}

For microtensile test, five specimens were used per group $(n=5)$. The sample size calculation of this research was based on previous laboratory studies $(18,19)$. After the treatments described in Table 1, specimens were hybridized with a self-etch adhesive system (Clearfil SE Bond, Kuraray, Japan) applied according to the manufacturer's instructions and light cured using a LED curing unit (Radii-Cal, SDI, Victoria, Australia). Using a silicon matrix, resin composite buildups (Z350XT, 3M ESPE, St. Paul, MN, USA) were constructed on the dentin surfaces in $2 \mathrm{~mm}$ increments, each light cured for $20 \mathrm{~s}$ with an irradiance of $1200 \mathrm{~mW} /$ $\mathrm{cm}^{2}$ (Radii-Cal, SDI). After $48 \mathrm{~h}$ of storage in distilled water, the bonded specimens were serially sectioned in the " $x$ " and " $y$ " directions across the bonded interfaces (IsoMet 1000, Buehler, Lake Bluff, IL, USA) to obtain sticks with a cross-sectional area of approximately $1.0 \mathrm{~mm}^{2}$. Five sticks were evaluated per specimens, totalizing twenty-five sticks per group $(18,19)$.

Table 1. Descritption of groups

\begin{tabular}{lc}
\hline Group & Treatment \\
\hline Control & $2.5 \% \mathrm{NaOCl}$ for $30 \mathrm{~min}$ \\
AR15 & $2.5 \% \mathrm{NaOCl}$ for $30 \mathrm{~min}+$ Argon Plasma for $15 \mathrm{~s}$ \\
AR30 & $2.5 \% \mathrm{NaOCl}$ for $30 \mathrm{~min}+$ Argon Plasma for $30 \mathrm{~s}$ \\
AR45 & $2.5 \% \mathrm{NaOCl}$ for $30 \mathrm{~min}+$ Argon Plasma for $45 \mathrm{~s}$ \\
\hline
\end{tabular}

The sticks had their cross-sectional area at adhesive interfaces measured with a digital caliper (MPI/E-101, Mytutoyo, Tokyo, Japan) and individually fixed to a microtensile device (ODMT03d, Odeme Biotechnology, Joaçaba, SC, Brazil) with cyanoacrylate glue (Loctite Superbonder Gel ${ }^{\circledR}$, Henkel Adesivos LTDA, Itapevi, SP, Brazil) and loaded under tension using a universal testing machine (EMIC DL 2000, São José dos Pinhais, PR, Brazil) at a crosshead speed of $1.0 \mathrm{~mm} / \mathrm{min}$ until failure. The $\mu$ TBS $(\mathrm{MPa})$ was obtained dividing the load at failure $(\mathrm{N})$ by the cross-sectional area $\left(\mathrm{mm}^{2}\right)$.

For statistical analysis, normal distribution of the $\mu$ TBS data was checked using the Kolmogorov-Smirnov test. Difference between groups was analyzed using the ANOVA and Tamhane tests $(\mathrm{p}<0.05)$.

Failure modes were evaluated at 40x magnification (SZ61TR Olympus, Tokyo, Japan) and classified as adhesive (at resin/dentine interface); cohesive (in resin or in dentin) and mixed (combined fracture) (20). Representative specimens from each group were evaluated by scanning electron microscopy at $1500 \times, 2500 x$ and 5000x magnifications (Phenom ProX, Phenom-World, Eindhoven, Holland).

\section{FTIR Analysis}

In order to analyze the effect of the treatments in dentin, the three remaining dentin surfaces of each group were evaluated by Fourier transform infrafred spectroscopy (FIIR). Infrared analysis was performed on a Nicolet 6700 spectrometer (Thermo Scientific, Waltham, MA, USA) in ATR mode and all spectra were acquired in absorbance mode in the $650-4000 \mathrm{~cm}^{-1}$ range. FIIR analyses were performed before and after adhesive application. In order to compare the degree of conversion of the adhesive in different groups, the relation $(R)$ between the absorbance peaks intensity of aliphatic $\mathrm{C}=\mathrm{C}(\mathrm{Al})$, located at $1635 \mathrm{~cm}^{-1}$, and aromatic $\mathrm{C}=\mathrm{C}(\mathrm{Ar})$, located at $1606 \mathrm{~cm}^{-1}$, was calculated in each spectrum using the equation: $(\mathrm{R})=\mathrm{Al} / \mathrm{Ar}(21)$, with the aromatic absorption function as an internal standard (22).

\section{Results}

\section{Microtensile Test}

Means and standard deviation of bond strength (in $\mathrm{MPa}$ ) for the Control, AR15, AR30 and AR45 groups were, respectively, $13.67 \pm 8.1,3.81 \pm 6.4,20.86 \pm 9.0$ and $1.51 \pm 6.8$. Control, plasma $15 \mathrm{~s}$ and $45 \mathrm{~s}$ showed the lowest values, without statistically significant difference between them ( $p>0.05$ ). The plasma treatment for $30 \mathrm{~s}$ increased the bond strength, showing the highest value and differing significantly form the other groups $(p<0.05)$.

\section{Failure Mode}

The distribution of the failure modes observed in optic 
microscopy is in Figure 1. Compared with the other groups, AR30 had significantly less adhesive fractures, showing higher values of cohesive or mixed patterns. Control, AR15 and AR45 showed high numbers of adhesive fractures and the first had no cohesive failures. Figure 2 shows representative images of different fracture patterns.

\section{FTIR Analysis}

FIIR spectra from different groups without adhesive system application are in Figure 3A. Spectra were
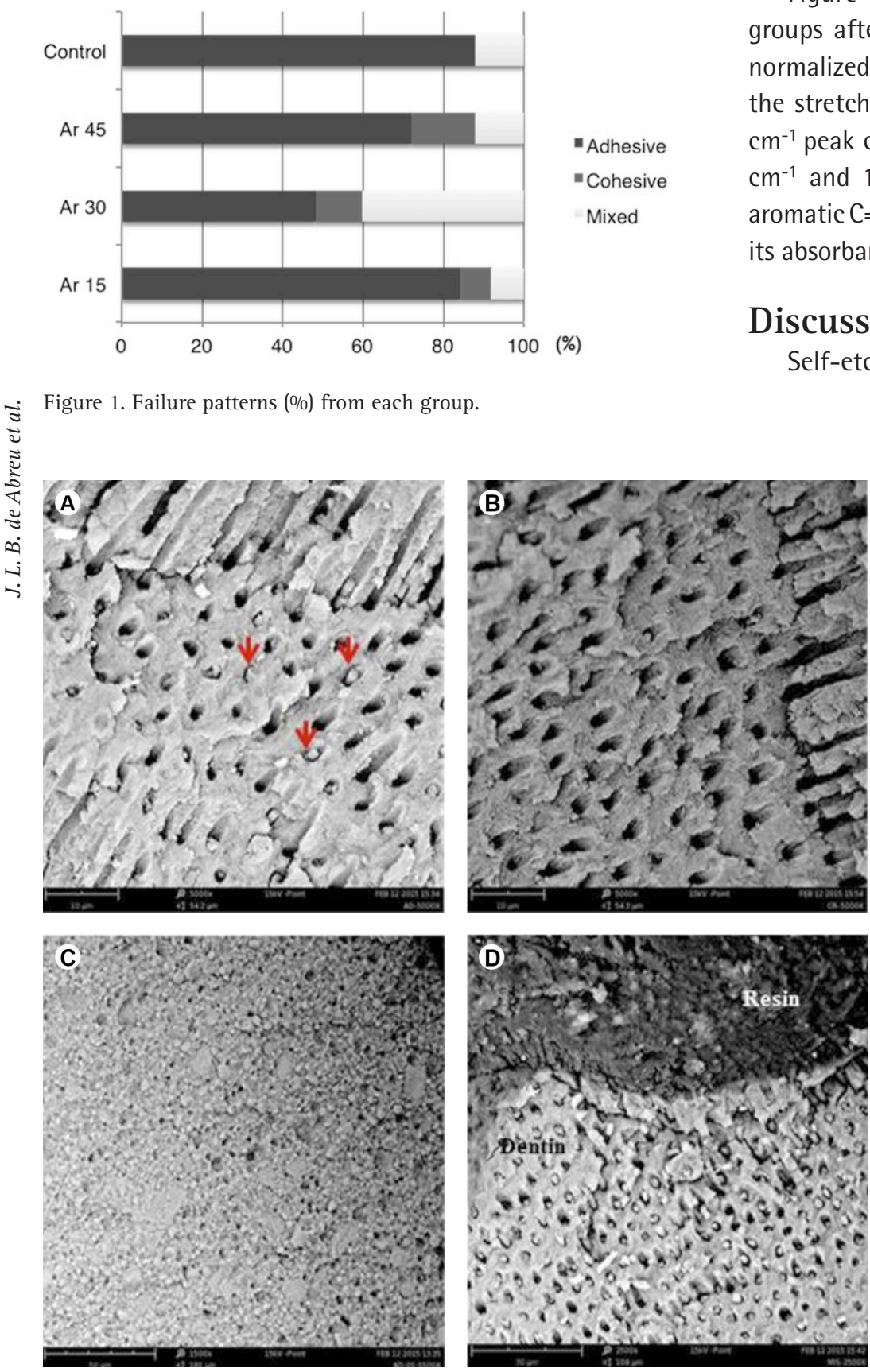

Figure 2. Representative SEM images of different failure patterns: adhesive (A), cohesive in resin (B), cohesive in dentin (C) and mixed (D). In adhesive failure, adhesive tags may be seen inside dentin tubules (red arrows). normalized using the phosphate peak at $1025 \mathrm{~cm}^{-1}$. Modifications observed between the $1400 \mathrm{~cm}^{-1}$ and 1700 $\mathrm{cm}^{-1}$ peaks demonstrate chemical changes in organic structure of dentin, where the peak close to $1600 \mathrm{~cm}^{-1}$ corresponds to the stretching vibration of the $\mathrm{C}=0$ bond $(v \mathrm{C}=0)$ from amide $\mathrm{I}$. The $1445 \mathrm{~cm}^{-1}$ peak corresponds to the carbonate band (23). The band between 1500 and 1600 $\mathrm{cm}^{-1}$ corresponds to the stretching vibration of $\mathrm{C}-\mathrm{N}$ bond ( $v \mathrm{C}-\mathrm{N})$ from amide II. The AR30 band close to $3.000 \mathrm{~cm}^{-1}$ represents the stretching vibration of the $\mathrm{C}-\mathrm{H}$ bond $(v \mathrm{C}-\mathrm{H})$ and at $3.500 \mathrm{~cm}^{-1}$ to $\mathrm{O}-\mathrm{H}(\mathrm{vO}-\mathrm{H})$.

Figure 3B shows the FIIR spectra from different groups after adhesive system application. Spectra were normalized using the $1720 \mathrm{~cm}^{-1}$ peak that corresponds to the stretching vibration of $\mathrm{C}=0$ bond $(v \mathrm{C}=0)$. The 1155 $\mathrm{cm}^{-1}$ peak corresponds to $\mathrm{C}-\mathrm{OH}$ bond $(\mathrm{vC}-\mathrm{OH})$. The 1635 $\mathrm{cm}^{-1}$ and $1606 \mathrm{~cm}^{-1}$ peaks correspond to aliphatic and aromatic $\mathrm{C}=\mathrm{C}$ bonds, respectively, and the relation between its absorbance peak intensity $(\mathrm{R})$ is in Table 2 .

\section{Discussion}

Self-etch adhesives, especially those containing 10MDP functional monomer, are a reliable method of bonding to dentin. The use of self-etch adhesives allows for a less sensitive technique, because it involves fewer steps. Different from systems that use phosphoric acid etching, in this system the collagen fibers remain protected by the hydroxyapatite and do not undergo hydrolase, which is advantageous for bonding durability (24).

Deproteinizing effect of sodiumhypochlorite $(\mathrm{NaOCl})$ pretreatment on smear layer-covered dentine for a short time (15 s) had no negative effect on bond strength of self-etch adhesive to dentin. However, from $30 \mathrm{~s}$ or more, it reduced the bond strength values compared with non-treated dentin (25). This occurs due the residual oxidizing effect in $\mathrm{NaOCl}$-treated dentine, causing premature chain termination and incomplete resin polymerization of adhesive materials (8).

Non-thermal plasma treatment usually acts modifying or etching surfaces. The first acts generally creating new chemical structures. Etching is the removal of chemical structures from the surface. Previous studies observed that 
argon plasma before restoration improved the adhesive properties of dentin $(13,14)$.

In the present study, this treatment was proposed in order to restore the bond strength of the $\mathrm{NaOCl}$-treated dentin. Short terms (15,30 and 45s) were evaluated to allow its clinical use. Additionally, it was previously observed that argon plasma treatment for $30 \mathrm{~s}$ improved bond strength of adhesive systems to dentin and longer exposure time may decrease bond strength values (13).

When argon plasma treatment was compared with

Table 2. Ratio between aliphatic and aromatic $\mathrm{C}=\mathrm{C}$ bonds

\begin{tabular}{ll}
\hline Group & Al/Ar ratio \\
\hline Control & 1.083214853 \\
AR15 & 1.444589764 \\
AR30 & 2.188986233 \\
AR45 & 1.538590604 \\
\hline
\end{tabular}
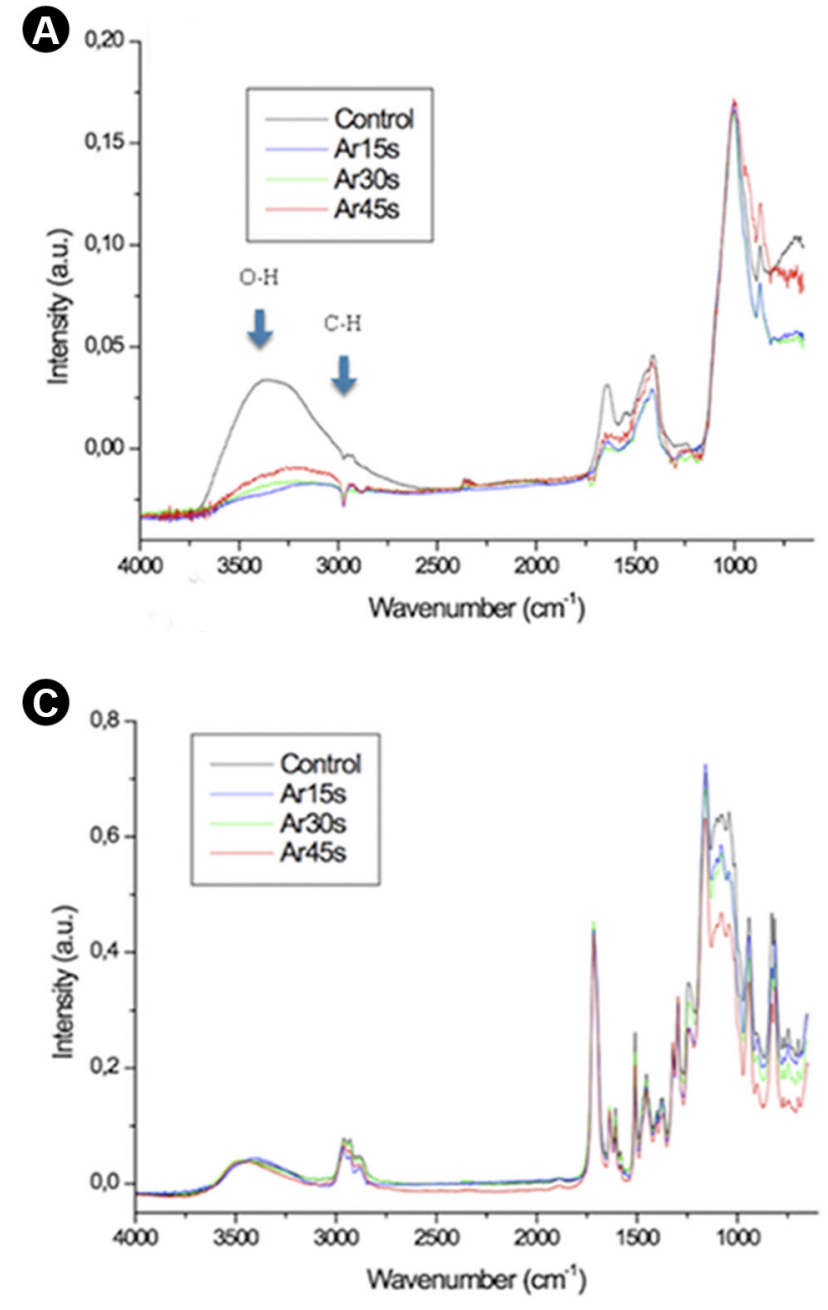

control group, the lowest values of bond strength were obtained from control and argon plasma treatment for 15 and $45 \mathrm{~s}$, as confirmed by the failure patterns. These groups showed higher amount of adhesive fractures. On the other hand, fracture patterns of argon plasma for 30 s confirmed the higher bond strength values, showing less adhesive fractures and more cohesive and/or mixed fractures.

FIIR analysis showed that plasma reduced significantly the $\mathrm{OH}$ functionality on the dentin surface. Observing the band between $1400 \mathrm{~cm}^{-1}$ and $1700 \mathrm{~cm}^{-1}, \mathrm{NaOCl}$ irrigation reduced the amides grouping of the smear layer. Plasma treatment for $15 \mathrm{~s}$ further reduces amide I (peak at 1640 $\mathrm{cm}^{-1}$ ) and treatment by $30 \mathrm{~s}$ and $45 \mathrm{~s}$ completely removed it. Plasma treatment also reduced amide II (1500-1600 $\mathrm{cm}^{-1}$ corresponds to the stretching vibration of $\mathrm{C}-\mathrm{N}$ bond). Argon plasma for 30 s showed a difference in the aromatic amines (1250-1335 $\mathrm{cm}^{-1}$ corresponds to the stretching vibration of $\mathrm{C}-\mathrm{N}$ bond) and in the carbonyl stretch (around 1760 $\mathrm{cm}^{-1}$ ). The carbonyl groups on the surface are associated
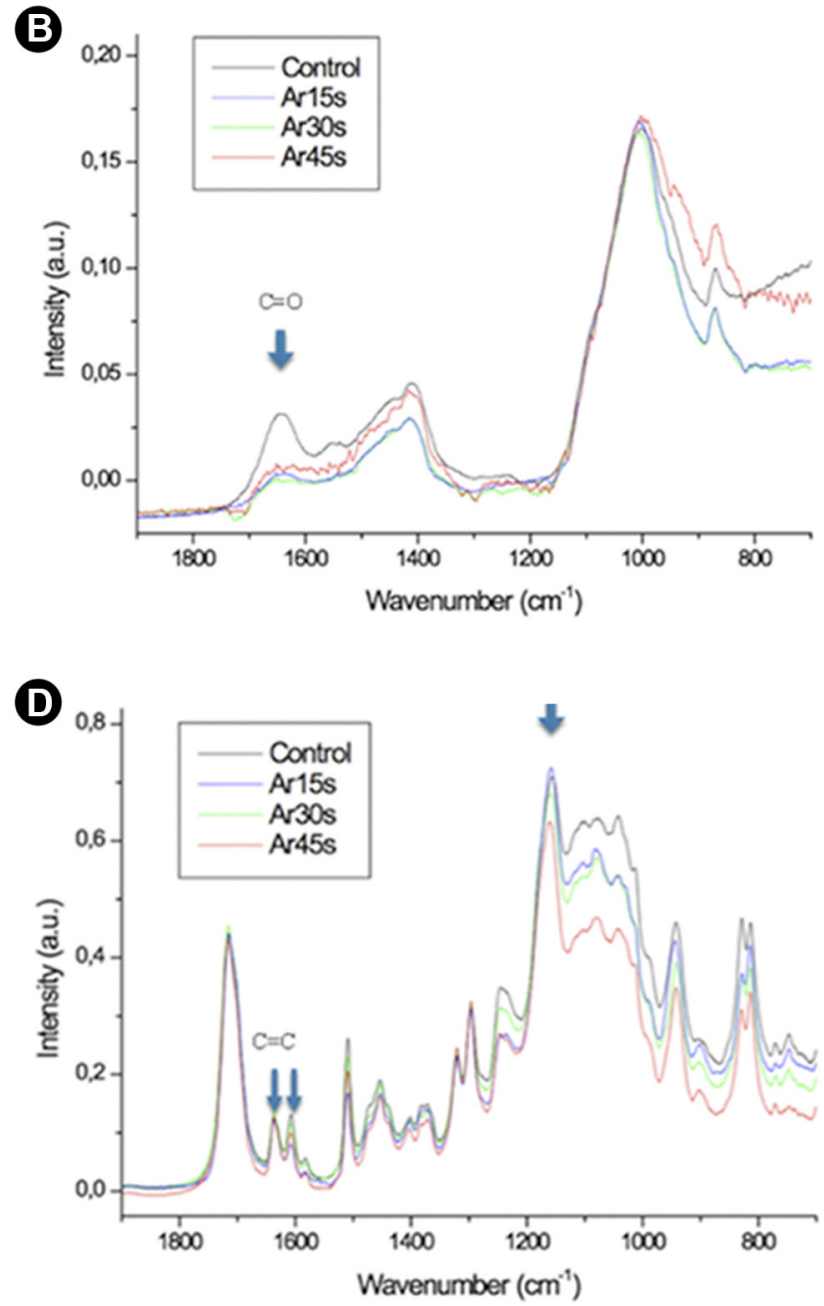

Figure 3. FTIR spectra of different groups without adhesive system application (A) and FTIR spectra of different groups after adhesive system application (B). 
with organic components of the smear layer and dentin (collagen fibrils). May be it increased hydrogen bonding interactions of the collagen fibrils with the adhesive that was subsequently applied to the dentin surfaces for test specimen preparation, and in this way favored the adhesion process. When argon plasma of $45 \mathrm{~s}$ FTIR spectrum is analyzed, it can be observed that, in relation to the phosphate peak, all peaks increased. As the phosphate peak was the one used for normalization of all spectra, this increase of all peaks may be related to a decrease in the phosphate content of the dentin. Thus, the negative results of $45 \mathrm{~s}$ may be associated with a prolonged plasma exposure that could start degrading the dentin inorganic structure with the reduction of phosphate species in relation to the carboxylic groups.

After adhesive system application, chemical alterations were also observed in plasma treated groups. Peak of 1155 $\mathrm{cm}^{-1}$ refers to $\mathrm{C}-\mathrm{OH}$ bonding $(\mathrm{v}-\mathrm{OH})$, where argon $30 \mathrm{~s}$ group showed lower formation of $\mathrm{C}-\mathrm{OH}$ bonds compared with other groups. $\mathrm{C}-\mathrm{OH}$ bonding results in a shorter polymer chain, which is an indication of a low degree of polymerization. Another indication is that argon plasma $\therefore$ of $30 \mathrm{~s}$ showed higher values in the relation between the aliphatic $\mathrm{C}=\mathrm{C}$ bonding (peak at $1635 \mathrm{~cm}^{-1}$ ) and aromatic $\mathrm{C}=\mathrm{C}$ bonding (peak at $1608 \mathrm{~cm}^{-1}$ ), indicating a higher degree of conversion of the adhesive in this group. This higher conversion is associated with the increase of the $\stackrel{4}{-}$ aliphatic $\mathrm{C}=\mathrm{C}$ bonding since there has been no change in the aromatic $\mathrm{C}=\mathrm{C}$ bonding. This finding may explain the higher bond strength values obtained in microtensile test in the present study for $30 \mathrm{~s}$.

The findings of the present study indicated that argon plasma treatment for $30 \mathrm{~s}$ improved the bond strength of dentin previously exposed to $\mathrm{NaOCl}$. According to other recent studies, the chemical changes and their influence on adhesive properties promoted by plasma treatment have been demonstrated $(13,14)$. From the statistical data, it seems that argon plasma treatment is a promising procedure to improve bonding quality of composite to dentin. Although, further studies should be done to gather more details of argon plasma effect on the organic component of dentin, analyzing the different periods of application and its implication on adhesive properties, establishing a standard protocol for argon plasma treatment.

It may be concluded that non-thermal argon plasma treatment for $30 \mathrm{~s}$ improved $\mu$ TBS of Clearfil SE bond to $\mathrm{NaOCl}$-treated dentin, promoting chemical changes in the dentin structure.

\section{Resumo}

Estudos vêm demonstrando uma diminuição na resistência adesiva em dentina tratada com hipoclorito de sódio ( $\mathrm{NaOCl})$. 0 objetivo desse estudo foi avaliar o efeito do plasma de argônio não-térmico na resistência de união de um sistema adesivo autocondicionante à dentina exposta ao $\mathrm{NaOCl}$. Trinta e duas superficies dentinárias lisas de incisivos bovinos foram imersas em $\mathrm{NaOCl}$ a 2,5\% por 30 min para simular o passo de irrigação durante o tratamento endodôntico. Os espécimes foram divididos em 4 grupos $(n=8)$, de acordo com o tratamento de superfície: Controle (sem tratamento de plasma), AR15 (plasma de argônio por 15s), AR30 (plasma de argônio por 30 s) e AR45 (plasma de argônio por 45 s). Para teste de resistência de união por microtração, cinco espécimes foram utilizadas por grupo. Em cada grupo, os espécimes foram hibridizados com um sistema adesivo autocondicionante (Clearfil SE Bond, Kuraray) e blocos de resina composta foram construídos. Após $48 \mathrm{~h}$ de armazenamento em água, os espécimes foram seccionados em palitos (5 por dente - 25 por grupo) e submetidos ao teste de resistência de união por microtração ( $\mu$ TBS) até a fratura, avaliando o padrão de fratura. Três amostras por grupo foram analisadas sob espectroscopia por FTIR para verificar as modificações químicas produzidas pelos tratamentos na dentina. Os dados de microtração foram avaliados estatisticamente utilizando os testes de ANOVA e Tamhane $(p<0,05)$. AR30 apresentou o maior $\mu$ TBS $(20,86 \pm 9,0)$. AR15 $(13,81 \pm 6,4)$ e AR45 $(11,51 \pm 6,8)$ foram estatisticamente semelhantes ao controle $(13,67 \pm 8,1)$. A espectroscopia por FTIR mostrou que o tratamento de plasma produziu modificações químicas na dentina. Como conclusão, o tratamento de plasma de argônio não-térmico por 30 s produziu alterações químicas na dentina e melhorou o $\mu$ TBS do Clearfil SE Bond à dentina tratada com $\mathrm{NaOCl}$.

\section{Acknowledgements}

The authors would like to thank José Maria and Marcos Vinicius for technical support. This work was supported by the Brazilian agency Capes (PNPD) and FAPERJ. The authors deny any conflicts of interest related to this study.

\section{References}

1. $\mathrm{Ng}$ YL, Mann V, Rahbaran S, Lewsey J, Gulabivala K. Outcome of primary root canal treatment: Systematic review of the literature-part 2 . Influence of clinical factors. Int Endod J 2008;41:6-31.

2. Chugal NM, Clive JM, Spanberg LSW. Endodontic treatment outcome: effect of the permanent restoration. Oral Surg Oral Med Oral Pathol Oral Radiol 2007;104:5761-5826.

3. Gillen BM, Looney SW, Gu LS, Loushine BA, Weller RN, Loushine RJ, et al.. Impact of the quality of coronal restoration versus the quality of root canal fillings on success of root canal treatment: a systematic review and meta-analysis. J Endod 2011;37:895-902.

4. Peters OA. Current challenges and concepts in the preparation of root canal systems: A review. J Endod 2004;30:559-567.

5. Paqué F, Peters OA. Micro-computed tomography evaluation of the preparation of long oval root canals in mandibular molars with the self-adjusting file. J Endod 2011;37:517-521.

6. Dutner J, Mines P, Anderson A. Irrigation trends among American Association of Endodontists members: a web-based survey. J Endod 2012;38:37-40.

7. Zehnder M1.Root canal irrigants. J Endod 2006;32:389-398.

8. Nikaido T, Ishihara K, Yamamoto T, Kojima M, Nagata K, Nakabayashi N. Photocurable bonding liner for teeth. Part IV. DSC analysis of photopolymerization. Shika Zairyo Kikai. 1988;7:841-848.

9. Deng D, Yang H, Guo J, Chen X, Zhang W, Huang C. Effects of different artificial ageing methods on the degradation of adhesive-dentine interfaces. J Dent 2014;42:1577-1585.

10. Marques EF, Bueno CE, Veloso HH, Almeida G, Pinheiro SL. Influence of instrumentation techniques and irrigating solutions on bond strength of glass fiber posts to root dentin. Gen Dent 2014;62:50-53.

11. Martinho FC, Carvalho CA, Oliveira LD, Farias de Lacerda AJ, Xavier AC, Gullo Augusto $M$, et al.. Comparison of different dentin pretreatment protocols on the bond strength of glass fiber post using self-etching adhesive. J Endod 2015;41:83-87.

12. Cunha LF, Furuse AY, Mondelli RF, Mondelli J. Compromised bond 
strength after root dentin deproteinization reversed with ascorbic acid. J Endod 2010;36:130-134.

13. Ritts AC, Li H, Yu Q, Xu C, Yao X, Hong L, et al.. Dentin surface treatment using a non-thermal argon plasma brush for interfacial bonding improvement in composite restoration. Eur J Oral Sci 2010;118:510516.

14. Costa Dantas MC, do Prado M, Costa VS, Gaiotte MG, Simão RA, Bastian FL. Comparison between the effect of plasma and chemical treatments on fiber post surface. J Endod 2012;38:215-218.

15. Pan J, Sun $K$, Liang $Y$, Sun $P$, Yang $X$, Wang J, et al.. Cold plasma therapy of a tooth root canal infected with Enterococcus faecalis biofilms in vitro. J Endod 2013;39:105-110.

16. Du T, Ma J, Yang P, Xiong Z, Lu X, Cao Y. Evaluation of antibacterial effects by atmospheric pressure nonequilibrium plasmas against Enterococcus faecalis biofilms in vitro. J Endod 2012;38:545-549.

17. Koibuchi H, Yasuda N, Nakabayashi N. Bonding to dentin with a selfetching primer: the effect of smear layers. Dent Mater 2001;17:122126.

18. Pimentel Corrêa AC1, Cecchin D2, de Almeida JF1, Gomes BP1, Zaia AA1, Ferraz CC3. Sodium Thiosulfate for Recovery of Bond Strength to Dentin Treated with Sodium Hypochlorite. J Endod 2016;42:284288.

19. Yildirim T, Ayar MK, Yesilyurt C. Influence of different Er,Cr:YSGG laser parameters on long-term dentin bond strength of self-etch adhesive. Lasers Med Sci 2015;30:2363-2368.

20. Betamar N, Cardew G, Van Noort R. Influence of specimens designs on the microtensile bond strength to dentin. J Adhes Dent 2007;9:159168 .
21. Arrais CA, Pontes FM, Santos LP, Leite ER, Giannini M. Degree of conversion of adhesive systems light-cured by LED and halogen light. Braz Dent J 2007;18:54-59.

22. Rueggeberg FA, Hashinger DT, Fairhust CW. Calibration of FTIR conversion analysis of contemporary dental resin composites. Dent Mater 1990;6:241-249.

23. Di Renzo M, Ellis TH, Sacher $E$, Stangel I. A photoacoustic FIIRS study of the chemical modifications of human dentin surfaces II: Deproteination. Biomat 2001;22:793-797.

24. Van Meerbeek B, Yoshihara K, Yoshida Y, Mine A, De Munck J, Van Landuyt KL. State of the art of self-etch adhesives. Dent Mater 2011:27:17-28

25. Kunawarote $S$, Nakajima $M$, Shida K, Kitasako Y, Foxton RM, Tagami J. Effect of dentin pretreatment with mild acidic $\mathrm{HOCl}$ solution on microtensile bond strength and surface pH. J Dent 2010;38:261-268.

Received March 18, 2016 Accepted May 20, 2016 